\title{
Protein deficiency, starvation and protein metabolism
}

\section{By D. J. Millward, Clinical Nutrition and Metabolism Unit, Department of Human Nutrition, London School of Hygiene and Tropical Medicine}

Changes in protein metabolism are central to many of the manifestations of malnutrition, whether they be mild growth retardation, severe stunting and wasting or the metabolic complications of oedema, fatty infiltration of the liver or hypoalbuminaemia. This paper reviews what is known about the effects of malnutrition on whole body protein turnover, and on the regulation of protein metabolism in the two key tissues muscle and liver, since the changes which occur in these tissues can have profound effects on the whole organism.

\section{Whole body protein turnover in malnutrition}

Measurements of whole body protein turnover in malnourished children were described by Picou \& Taylor-Roberts (1969) in a report in which whole body protein synthesis and breakdown was, somewhat surprisingly, increased above normal values. However, these measurements were made after the children had been fed for 2-9 d with sufficient energy and protein to allow catch-up growth so that there has always been a difficulty in differentiating between the initial malnourished state and rehabilitation. This has now been resolved with measurements made on children within $2 \mathrm{~d}$ of admission whilst being fed on a maintenance regime (Golden et al. 1977a). In these children rates of protein turnover were lower than in the same children when recovered (Fig. I). Rates of protein synthesis and breakdown were reduced by about $40 \%$. Since both measurements were made with the same dietary input it is clear that reduced turnover reflected the malnourished state rather than the immediate dietary input. In the more recent study (Golden et al. 1977a) measurements made on two children during the period of rapid weight gain indicate increased rates of both synthesis and breakdown above the values observed in recovered children. Combining the results of the two studies it would appear (Fig. I) that during catch-up growth whole body protein synthesis was increased by $70 \%$ and degradation by $50 \%$ above the values observed in the recovered children. Once again these changes in protein turnover appear to reflect the nutritional state of catch-up growth rather than the increased food intake since measurements made in recovered children given similar intakes did not indicate elevated rates of either protein synthesis or breakdown. On the contrary in recovered children fed on increasing amounts of protein and exhibiting increasing rates of protein retention; rates of protein synthesis were constant whereas rates of protein breakdown fell.

These results were obtained by a method involving the continuous administration (as an infusion or multiple dose) of ${ }^{15} \mathrm{~N}$ glycine (Picou \& Taylor$0029-665_{1} / 79 / 3^{81} 3^{-2009}$ sor.0o 1979 The Nutrition Society 


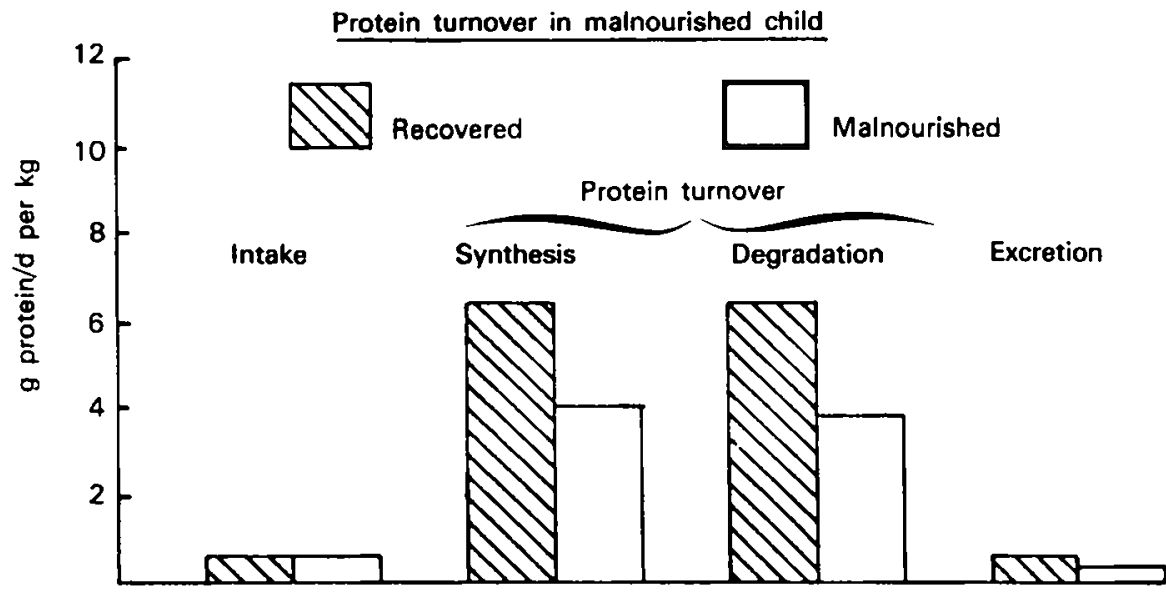

Protein turnover during recovery from PEM

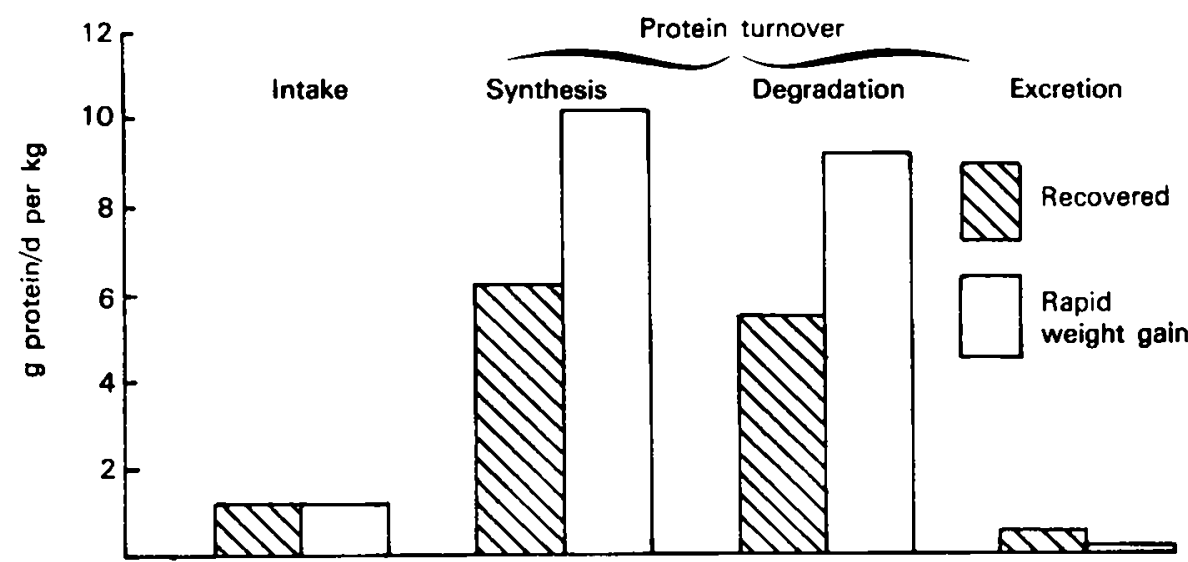

Fig. 1. Whole body protein turnover in malnourished, recovering and recovered children (Picou \& Taylor-Roberts, 1969, and Golden et al. 1977a).

Roberts, 1969; see Waterlow et al. 1978) and they have been confirmed by and large by a single dose method (Golden et al. $1977 b$ ) although the increases in protein breakdown observed during catch-up growth were not so pronounced in the latter study.

Measurements of whole body protein turnover in malnourished animals generally show reduced rates in chronic protein deficiency (Waterlow \& Stephen, 1967; Garlick et al. 1975; Millward, Garlic, Nnanyelugo et al. 1975) and during starvation (Lo \& Millward, I977) although elevated rates during rehabilitation are not observed in the rat (Millward et al. 1974; Lo \& Millward, 1977).

The reduced rate of whole body protein synthesis and breakdown in the malnourished child can result from two changes, changes in the turnover rate within individual tissues, or an altered body composition. Changes in body composition involve not only a generalized loss of soft tissues compared to skeleton and connective tissue (Waterlow et al. 1960) but also changes in relative weights of 
organs with different rates of turnover (see Waterlow et al. 1978). Thus brain is increased (Garrow et al. 1965), muscle is reduced (Standard et al. 1959) whilst the liver protein mass can vary in either direction. The problem in interpreting changes in total body protein turnover is similar to that of interpreting changes in metabolic rate. Brooke \& Cocks (1974) related BMR to total body potassium (amongst other things) on the grounds that TBK is an index of cellular mass and actual intracellular $K$ concentrations are only reduced in very severely malnourished children (Alleyne et al. 1970). Although TBK values were not measured in the children studied by Golden et al. (1977a) given their degree of wasting (they were on average $70 \%$ of expected weight for height) and the fact that reduced TBK is a common feature of all malnourished children, it is quite likely that much of the $40 \%$ fall in protein synthesis and breakdown was matched by a fall in TBK. Thus the average turnover rate of the lean tissue present in the malnourished child may not have been markedly depressed. However, since TBK is never elevated during rehabilitation turnover rates per TBK would certainly have been increased at this time.

At the level of the whole body, changes in protein turnover may be important because of the metabolic cost of protein synthesis. Thus protein turnover might be classed as a futile cycle, in the thermogenic sense, and the reduced cycling in malnutrition would conserve energy. This argument depends on the assumption that protein turnover is futile and therefore could be reduced without any functional impairment and that its energy cost is significant. As far as the first of these assumptions is concerned most of the measurements which have been made in individual tissues suggest that there is a characteristic rate, implying a functional significance to the particular rate of protein turnover (although it is not known what the functional significance is, see Millward et al. 1978). As far as the second assumption is concerned the only certainty is the metabolic cost of protein synthesis in terms of the known stoichiometry of peptide bond synthesis. The magnitude of this $(2 A T P+2$ GTP plus an extra ATP equivalent for associated RNA turnover and resynthesis) is about $3.5 \mathrm{~kJ}(0.85 \mathrm{kcal}) / \mathrm{g}$. On this basis, assuming that the metabolic cost of protein breakdown is negligible, whole body protein turnover in the normal infant accounts for only $5 \%$ of total daily heat production (see Spady et al. 1976 for values) so that there is little potential for any useful adaptive change in the malnourished state. Even during catch-up growth the increased turnover still only accounts for about $9 \%$ of total daily energy expenditure. Only if protein synthesis is metabolically linked to other energetically expensive processes such as the sodium pump, perhaps through demands on amino acid transport, can changes in whole body protein turnover be considered to influence energy balance.

Changes in whole body protein turnover have also been discussed in relation to alterations in the efficiency of nitrogen retention. Certainly in the malnourished child maintenance requirements seem to be reduced since on intakes of $0.6 \mathrm{~g}$ protein $/ \mathrm{kg}$ per $\mathrm{d}$ a third was retained whereas this just produced balance in recovered children (Golden et al. 1977a). Because of the re-utilization of amino 
acids liberated by proteolysis, the replacement component of protein turnover should have very little direct influence on amino acid requirements. However, the efficiency of protein utilization depends ultimately on rates of amino acid oxidation and end product (i.e. urea and ammonia) formation and excretion and given the fact that amino acid concentrations affect their rates of oxidation (Krebs, 1972) and may affect rates of protein turnover, a relationship between protein turnover and the efficiency of protein utilization is much more likely.

\section{Muscle protein metabolism in malnutrition}

During normal growth the major part of protein and energy requirements are for muscle growth. In addition during malnutrition muscle is centrally involved in homoeostatic mechanisms of energy and protein metabolism not only because its protein mass represents the major non-fat energy store (see Millward \& Waterlow, 1978) but also through its role in branched-chain amino acid metabolism (see Adibi, 1976; Goldberg \& Tse Wen Chang, 1978. The subject has recently been reviewed, Waterlow et al. 1978 ).

\section{Sites of regulation of muscle growth}

Muscle growth involves the enlargement of the multi-nucleate contractile cells, the myofibres. This occurs consequent to the addition of new nuclei from satellite cells (lying between plasma and basement membrane, see Moss \& Leblond, 1970), and this accumulation of DNA is accompanied by a parallel accumulation of RNA and protein. Since RNA and protein are in dynamic state, their content can be regulated through changes in their rates of synthesis and breakdown.

The production of new nuclei in muscle is a crucial regulatory site since muscle growth rates and ultimate size seem to be determined by the rate and extent of DNA synthesis (Millward \& Waterlow, 1978; Laurent et al. 1978; Millward, 1978). The sensitivity of DNA synthesis is indicated by the observation that DNA accumulation in muscle appears to be more sensitive than protein accumulation in energy deficient rats ( Cheek \& Hill, 1970), in rats marginally protein depleted over several generations (Millward, Garlick, Stewart et al. 1975) and in protein deficient rats (Howarth, 1972).

While the potential for protein synthesis in muscle is determined by the number of nuclei (or DNA content), the actual rate depends on the amount and activity of the translational apparatus, in .other words the capacity for protein synthesis (amount of RNA) and the RNA activity (protein synthesis rate/unit RNA). Each of these parameters very markedly in response to acute and chronic changes in nutritional status (Millward et al. 1973; Millward et al. 1974; Millward \& Waterlow, 1978).

Muscle protein content is regulated through the balance between synthesis and degradation and there is ample evidence that degradation is also an important regulating site. However, the importance of regulation at this latter site is not easily assessed because of the often paradoxical changes in the rate of the process i.e. increases during growth and decreases during wasting (see Millward et al. 
1978). This means that it is important to consider changes in protein turnover in muscle not only as far as they effect changes in protein balance but also in terms of alterations of replacement rates of muscle proteins.

\section{Regulation of muscle protein replacement rates}

The paradoxical way in which the degradation rates of muscle proteins change is illustrated in Fig. 2. In normally growing rats replacement rates are highest during the most rapid growth, these rates fall during protein deficiency when net catabolism occurs and the rates are increased during rehabilitation. These changes appear to occur in a similar fashion in man judging by the excretion rates of 3 methyl histidine which is an index of muscle protein breakdown (see Young \& Munro, 1978). Why these changes occur is not understood but one possible rationale is that the growth process itself induces some unavoidable wastage during the remodelling of the contractile cell so that during growth there is an 'anabolic increase' in protein degradation (see Millward et al. 1978). While this would account for the fall in replacement rates when growth is suppressed it would not account for the apparent fall (judging by 3-methyl histidine excretion) which occurs in non-growing adult man during fasting (Young et al. 1973). Because of the fall in $T_{3}$ levels during fasting (Portnay et al. 1974) and the demonstration that

Muscle protein turnover during rapid growth
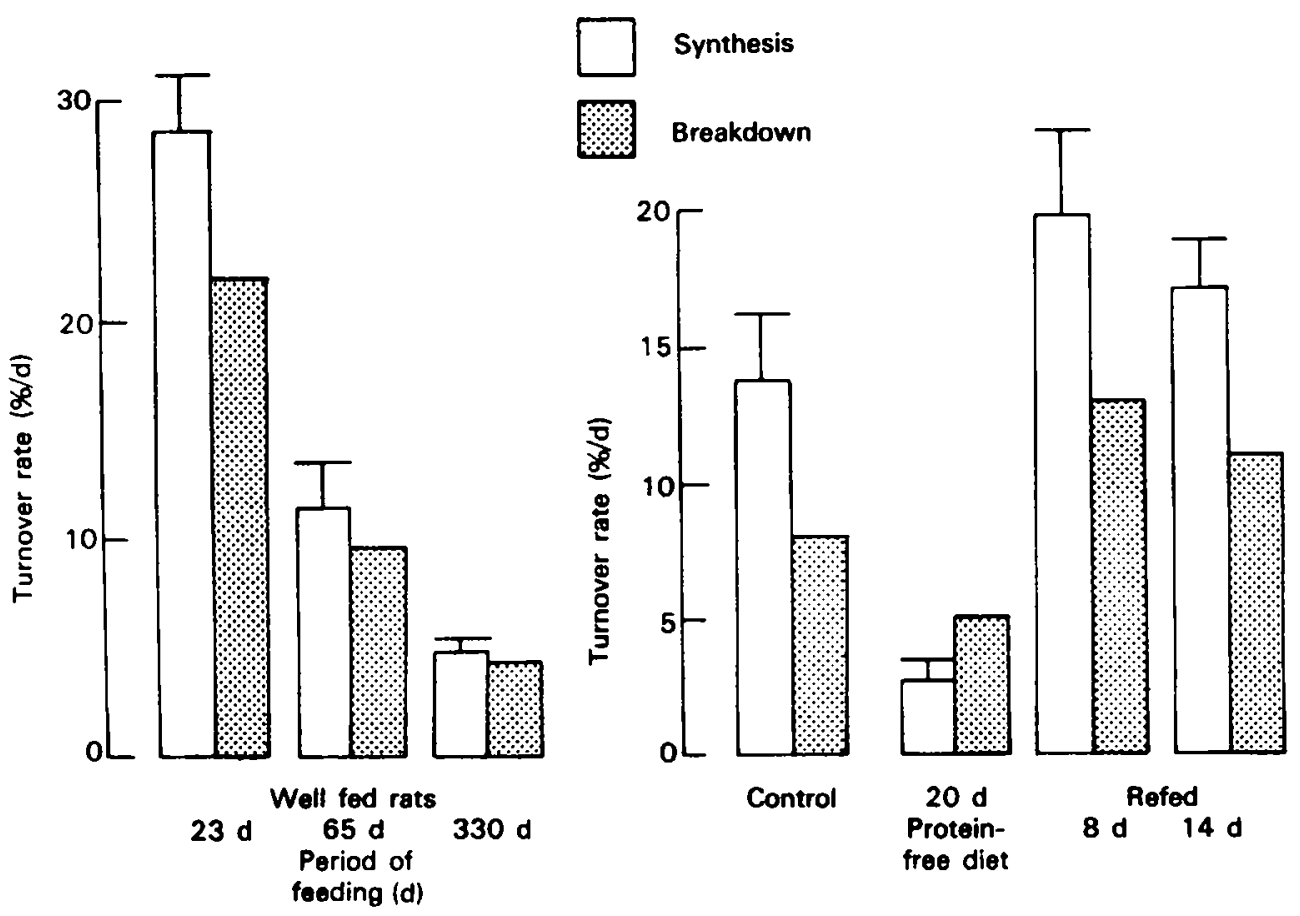

Fig. 2. Muscle protein turnover during growth and development after a protein free diet and during rehabilitation. Protein replacement rates are higher during growth and fall in malnutrition. 
thyroid hormones appear to regulate the levels of those lysosomal enzymes involved in protein degradation (de Martino \& Goldberg, 1978), the possibility exists that replacement rates of muscle proteins reflect thyroid activity. Our own recent measurements of this certainly indicate that in thyroid deficient states in rats (hypophysectomy or thyroidectomy) replacement rates of muscle proteins are reduced and treatment with $T_{3}$ at physiological doses restores normal values (D. J. Millward, M. A. Holliday \& P. C. Bates, unpublished results). However it does not appear that altered thyroid status is responsible for the reduced muscle protein turnover in protein deficient rats since circulating $T_{3}$ levels are elevated in this condition (M. Cox, S. Dalal, C. R. C. Heard \& D. J. Millward, unpublished results). Furthermore although some populations of malnourished children have been described with hypothyroidism (Beas et al. 1966; Graham \& Blizzard, 1973; Pimstone et al. 1973) these are generally recognized as exceptions to the more common finding of normal thyroid status. Thus in protein deficiency alterations in muscle protein replacement rates cannot (at the moment) be explained in terms of altered thyroid hormone levels. However thyroid induced changes in protein turnover may be important amongst those marginally malnourished populations which survive on very low energy intakes. The reduced energy expenditure in these cases may include hypothyroid-induced reductions in protein turnover.

\section{The regulation of muscle protein balance}

Muscle growth and protein balance appear to be regulated through two mechanisms which are probably difficult to separate. The first of these is muscle stretch. This is important not just in terms of the induced hypertrophy of individual muscles but also in terms of normal growth since it has been postulated that in growing animals muscles are stretched following bone growth (Stewart, 1972). The fact that the malnourished child can grow at some twenty times the rate of a normal child may well reflect the fact that the marked reduction in muscle mass per unit of bone length which occurs in the malnourished child increases the extent to which muscles are stretched. Catch-up growth would then occur until the normal relationship between bone length and muscle mass was restored after which time muscle growth would be limited by bone growth.

The other general mechanism of regulation of muscle growth is the direct hormonal regulation and since bone growth is also hormonally regulated then hormonal regulation of muscle growth must be seen to occur directly and indirectly. Of the hormones generally recognized to be involved (insulin, growth hormone, cortisol, and $T_{3}$ ) insulin and growth hormone together with $T_{3}$ are recognized as anabolic whilst cortisol is catabolic, However, the way in which these hormones interact with each other and with the potential regulatory sites in muscle is not at all clear. Insulin is probably the best understood anabolic effector, not only stimulating transport but also regulating protein synthesis at the level of initiation of translation and suppressing protein breakdown (Jefferson et al. 1977). Insulin's role in the regulation of RNA synthesis is not as clearly defined and it has not been demonstrated to regulate DNA synthesis. The role of growth hormone in 
muscle growth regulation is being re-evaluated in terms of the involvement of the somatomedins as effectors of growth hormone action (see Luft \& Hall, 1975). It is not known to what extent the requirement for growth hormone to allow DNA synthesis to occur (e.g. Cheek \& Hill, 1970) reflects a direct action on muscle satellite cells or a secondary response to the induction of bone growth by the hormone. Glucocorticoids (cortisol in man, corticosterone in rats) are recognized as catabolic suppressing DNA synthesis (Goldberg \& Goldspink, 1975) and protein synthesis (Millward, Garlick, Nnanyelugo et al. 1976; Rannels et al. 1977; Shoji \& Pennington, 1977), but little is known how these changes are brought about.

Because insulin and glucocorticoids have opposing effects (not only in terms of protein balance, but also in terms of glucose uptake by muscle) it is not surprising to see the inverse changes in their concentrations in malnutrition. This is most clearly documented in rats in which energy deficiency, which induces the most marked loss of muscle protein, is accompanied by a very marked increase in the ratio corticosterone:insulin (Coward et al. 1977; see Fig. 3). It is interesting that the ratio corticosterone:insulin is only marginally elevated in protein deficiency even though there is an immediate suppression of DNA synthesis and over-all growth. This raises the question of whether the involvement of glucocorticoids in growth suppression involves a class of receptors which are much more sensitive than those which mediate the massive catabolism observed in energy deficiency or starvation. Thus in conditions where the diagnosis might be 'failure to thrive'

Liver protein $(\mathrm{mg})$

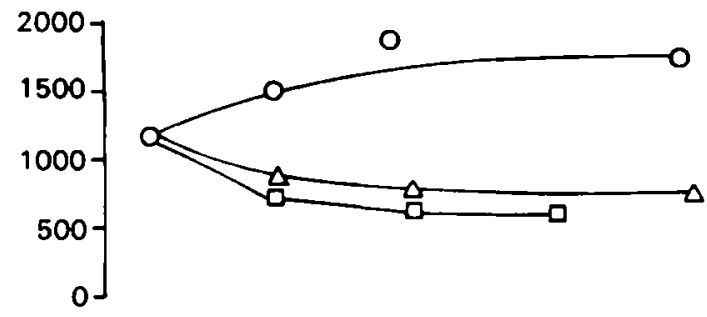

Muscle protein $(\mathrm{mg})$

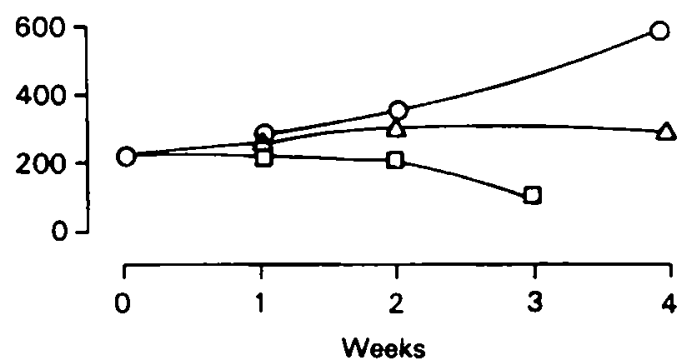

Plasma albumin $(g / l)$

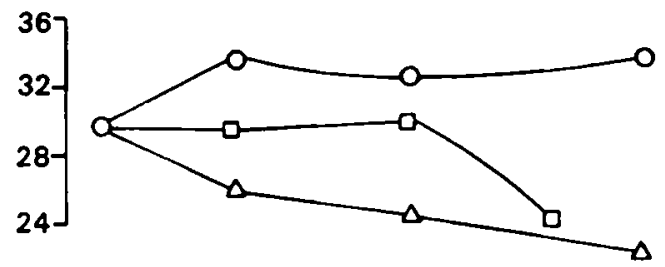

Corticosterone: insulin

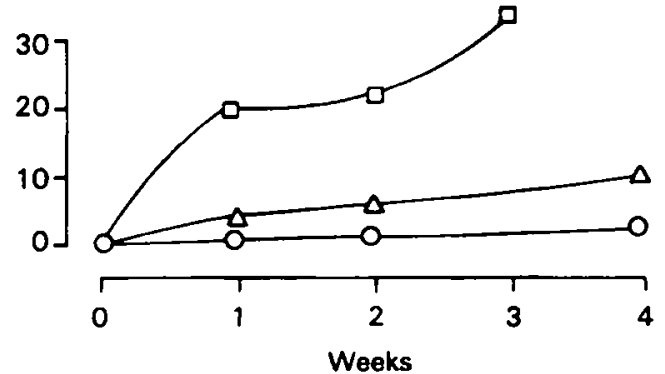

Fig. 3. Effects of $(\Delta)$, protein deficiency or $(\square)$, energy deficiency on liver and muscle protein content, plasma albumin and the ratio corticosterone:insulin in the rat. (O), control. (Coward et al. 1977). The loss of muscle protein in energy deficiency is associated with very marked increases in the ratio corticosterone:insulin. While the rate of loss of liver protein is similar in each case, albumin concentrations are maintained in the energy deficient rats. How this is achieved is not known. 
perhaps as a result of emotional stress or mild infections, the growth retardation may result from the marginal changes in the balance between cortisol and the anabolic hormones. Certainly the mechanism by which muscle protein is lost is quite different in protein deficiency than in energy deficiency or starvation. In the former case protein synthesis and breakdown are both reduced (Garlick et al. 1975) whilst in the latter case protein breakdown is increased (Millward, Garlick, Nnanyelugo et al. 1976).

\section{Metabolic significance of muscle wasting in malnutrition}

Traditionally it has been argued that the losses of muscle protein during malnutrition provide precursors for hepatic gluconeogenesis as well as essential amino acids for protein synthesis in the liver. In the last decade with the recognition that some amino acids are metabolized in muscle, there has been a great deal of discussion of the nature and extent of amino acid metabolism in muscle. This centres around the extent of branched chain amino acid oxidation in muscle (see Adibi, 1976) and the source of the nitrogen and carbon components of the alanine and glutamine which occur in excessive amounts in the amino acids effluxing from muscle in post absorptive man (see Aoki et al. 1974; Ruderman, 1975; Felig, 1975; Goldberg \& Tse Wen Chang, 1978). These developments have changed a simple process into one which is seemingly much more complicated, and it is worthwhile briefly examining them.

When the composition of the amino acid efflux from muscle in post absorptive man is compared to that of muscle protein it is clear that the enrichment of the efflux with alanine and glutamine is balanced by a deficit of aspartate, glutamate and the branched-chain amino acids. The extent of this imbalance varies (see Waterlow et al. 1978) but the results of Aoki et al. (1974) indicate that it is about $37 \%$ (on a molar basis, assuming that glutamine accounts for $5 \%$ of muscle protein). Thus it can be immediately stated (Fig. 4) that about two-thirds of the amino acids liberated from muscle protein leave the tissue unchanged. Of the $37 \%$ which are deaminated little of their carbon skeletons are transformed to alanine or glutamine. The excess alanine $(18 \%)$ derives from glucose taken up by the muscle (Felig, 1975; Goldberg \& Tse Wen Chang, 1978) whilst nearly half the excess glutamine derives from glutamate taken up by muscle (Aoki et al. 1974). This leaves only $10 \%$ of potentially gluconeogenic carbon which is transformed in muscle (to glutamine) before it leaves and this is only used for gluconeogenesis after prior conversion to alanine in the gut (see Felig, 1975) or following uptake by the kidney which occurs in prolonged fasting or acidosis (see Cahill, 1970). The remaining carbon skeletons are either oxidized in situ or leave muscle as the $\alpha$-keto acids. The importance of amino acid deamination and oxidation in muscle results from the fact that the essential amino acids involved (the branched-chain amino acids particularly leucine), can be rate limiting for tissue protein synthesis: (this is because the abundance of leucine in proteins is high while the abundance in the free amino acid pool is rather low). Thus the amino acids effluxing from muscle 


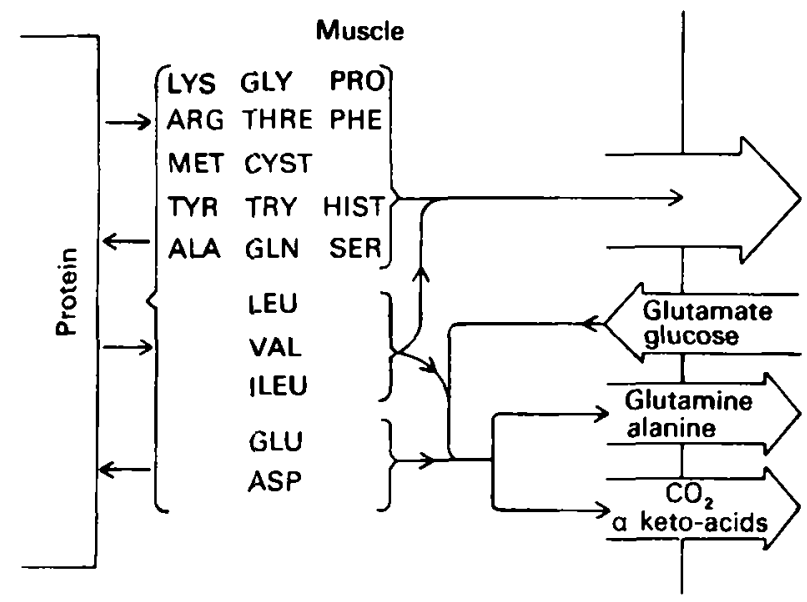

Fig. 4. Metabolic fate of muscle protein lost in fasting. Of the amino acids liberated from muscle protein two-thirds leave directly while the rest are deaminated, the nitrogen leaving as glutamine and alanine, and the carbon as $\mathrm{CO}_{2}$ or branched-chain $\alpha$ keto acids. Although the efflux is deficient in branched-chain amino acids their concentration may rise because they are produced at a faster rate than they can be oxidized.

tend to be depleted in branched-chain amino acids and this may prejudice the ability of the liver to maintain normal export protein synthesis as discussed below.

\section{The regulation of protein metabolism in liver}

As with muscle, regulation of liver growth or protein balance can be exerted at the level of DNA synthesis, RNA synthesis and breakdown and protein synthesis and breakdown. However there are some obvious differences between the two tissues. The first one of these is the fact that liver exports proteins to a considerable extent (up to a third of its own protein mass each day in the rat, see Waterlow et al. 1978) which means that it requires an amino acid supply equal to this just to maintain balance. Its position with respect to the gastrointestinal tract ensures that it is perfused with high concentrations after a meal, but the immediate loss of protein from the organ during fasting or following a protein free meal (Millward et al. 1974) indicates the result of an interruption of this supply. It can be shown that the loss of liver protein at this time is almost exactly equal to the rate of export protein synthesis which is maintained at the expense of liver cytoplasmic protein (Millward, Garlick, James et al. 1976).

This role in exporting protein may also explain why the regulation of liver protein balance is achieved through regulation of protein degradation (Mortimore \& Ward, 1976) rather than protein synthesis (Garlick et al. 1973), since any general regulatory mechanism affecting protein synthesis would probably affect export protein synthesis and this would be undesirable at least as far as acute changes are concerned. Protein degradation is suppressed by amino acid supply and insulin (Woodside \& Mortimore, 1972) and stimulated by glucagon (Woodside et al. 1974). Cortisol has a number of effects on liver being anabolic in stimulating 
RNA synthesis and some key glucogenic enzymes (see Waterlow et al. 1978), but catabolic in that it suppresses DNA synthesis and as a result the hyperlastic component of liver growth (Goldberg \& Goldspink, 1975).

A key question as far as the regulation of liver protein metabolism in PEM is concerned relates to the relative effects of protein or energy deficiency and/or a particular hormonal setting on the synthesis of albumin and the protein component of the very low density lipoprotein, since deficits in these proteins are factors in the aetiology of the oedema and fatty liver observed in PEM (see Whitehead \& Alleyne, 1972; Coward \& Fiorotto, 1979; Whitehead \& Lunn, 1979).

Thus the higher ratio cortisol:insulin observed in some populations of children or in energy deficient rats is said to protect against hypoalbuminaemia by promoting muscle breakdown and maintaining a sufficient supply of amino acids to allow export protein synthesis to continue. With a lower ratio cortisol : insulin (as seen in protein deficient rats) amino acid supply is not maintained and hypoalbuminaemia ensues. The experimental results in rats which support this thesis are shown in Fig. 3. This general thesis deserves further examination.

As far as albumin synthesis is concerned there has been no systematic study of the relative effects of energy or protein deficiency. In protein deficiency there is no doubt that albumin synthesis falls in children (e.g. James \& Hay, I968) or in rats (Kirch et al. 1968; see Waterlow et al. 1978) and this seems to involve a selective loss of active albumin mRNA (Pain et al. 1978a). In starvation however albumin synthesis has been reported to fall (Peters \& Peters, 1972) or be maintained as a proportion of total liver synthesis (Pain et al. 1978b). However even if albumin synthesis is maintained as a proportion of total liver protein synthesis in energy deficiency or starvation, the liver mass is not protected and tends to be just as small if not smaller compared with protein deficiency (Fig. 3). It is therefore difficult to reconcile the protection of albumin synthesis in energy deficiency with the clear lack of protection of the over-all liver mass.

It is also not clear whether there is sufficient supply of branched-chain amino acids to allow the maintenance of normal albumin synthesis in energy deficiency. As discussed above these amino acids comprise only a small proportion of the efflux from muscle in fasting. Pozefsky et al. (1976) report an output from muscle in $60 \mathrm{~h}$ fasted adults equal to about $22 \mathrm{mmol} / \mathrm{d}$ per $70 \mathrm{~kg}$ which is slightly less than the amount needed for albumin synthesis in the liver $(26 \mathrm{mmol} / \mathrm{d}$ per $70 \mathrm{~kg})$ and certainly would not support the synthesis of the other exported proteins. Furthermore in the starved rat the liver has been reported to give out branchedchain amino acids (Bloxham, 1972).

However, there are alternate potential sources of branched-chain amino acids. One of these is through the process of endocytosis which involves the uptake and degradation in the liver of plasma proteins. The quantitative importance of this is completely unknown. Another source is through the uptake of the $\alpha$-keto acids released from muscle after the deamination of the branched-chain amino acids (see Adibi, 1976). However since the transaminases are not very active in liver it is not known to what extent they could be reaminated there. 
Albumin levels in the plasma are regulated not only through alterations in synthesis, but also through changes in degradation rates and in albumin distribution between intra and extracellular compartments, thus the maintenance of normalbuminaemia in energy deficiency or with a high ratio cortisol : insulin may involve changes at these sites. There is a well documented fall in albumin breakdown during protein deficiency which is associated with the hypoalbuminaemia (e.g. James \& Hay, 1968; Kirsch et al. 1968; Hoffenberg, 1970). It would be unusual therefore if there was a rapid, more marked fall in breakdown in energy deficiency when albumin levels are normal. As far as albumin distribution is concerned it might be proposed that in energy deficiency or with an elevated ratio cortisol : insulin there is a marked shift in albumin distribution maintaining the intravascular concentration. This certainly occurs in protein deficiency to the extent that the fall in albumin concentration is much less than the over-all loss of total body albumin (Coward \& Sawyer, 1977). Once again however it has been proposed that the shift in albumin concentration is a response to the hypoalbuminaemia (James \& Hay, 1968), so that a shift associated with normalbuminaemia would be unusual. It is obvious that the answer to the problem of the maintenance of albumin levels in energy deficiency requires measurements of synthesis, breakdown and distribution all of which can be done with existing methods.

The author gratefully acknowledges generous financial assistance from the Muscular Dystrophy Group of Great Britain and the Medical Research Council.

\section{REFERENCES}

Adibi, S. A. (1976). Metabolism 25, 2877.

Alleyne, G. A. O., Millward, D. J. \& Scullard, G. H. (1970). F. Pediat. 76, 75.

Aoki, T. T., Brennan, M. F., Muller, W. A. \& Cahill, G. F. (1974). Adv. Enryme Reg. 12, 3.

Beas, F., Monckeberg, F., Horwitz, I. \& Figueroa, M. (s966). Pediatrics, Springfield 38, 1003.

Bloxham, D. L. (1972). Br. F. Nutr. 27, 233.

Brook, O. G. \& Cocks, T. (1974). Acta paediat. scand. 63, 817.

Cahill, G. F. (1970). N. Engl. J. Med. 28s, 668.

Cheek, D. B. \& Hill, D. E. (1970). Fedn Proc. Fedn Am. Socs esp. biol, 29, 1503.

Coward, W. A. \& Fiorotto, M. (1979). Proc. Nutr. Soc. 38, 51.

Coward, W. A. \& Sawyer, M. B. (1977). Br. 7. Nutr. 37, 127 .

Coward, W. A., Whitehead, R. G. \& Lunn, P. G. (1977). Br. F. Nutr. 38, 115.

de Martino, G. \& Goldberg, A. L. (1978). Proc. matn. Acad. Sci. U.S.A. 75, 1369.

Felig, P. (1975). A. Rev. Biochem. 44, 933 .

Garlick, P. J., Millward, D. J. \& James, W. P. T. (1973). Biochem. J. 136, 935.

Garlick, P. J., Millward, D. J., James, W. P. T. \& Waterlow, J. C. (1975). Biochim. biophys. Acta 414,71 .

Garrow, J. S., Fletcher, K. \& Halliday, D. (1965). J. clin. Invest. 44, 417.

Goldberg, A. F. \& Goldspink, D. F. (1975). Am. F. Physiol. 228, 310.

Goldberg, A. L. \& Tse Wen Chang (1978). Fedn Proc. Fedn Am. Socs exp. biol. $37,2301$.

Golden, M. H. N., Waterlow, J. C. \& Picou, D. (1977a). Clin. Sci. Mol. Med. 53, 473.

Golden, M. H. N., Waterlow, J. C. \& Picou, D. (1977b). Am. J. clin. Nutr. 30, 1345 .

Graham, G. G. \& Blizzard, R. M. (1973). In Endocrine Aspects of Malnutrition, p. 205 [L. I. Gardner and P. Amacher, editors]. Santa Ynez, California: Kroc Foundation.

Hoffenberg, R. (1970). In Plasma Protein Metabolism, Chapter 15 [M. A. Rothschild, and T. A. Waldmann, editors]. New York and London: Academic Press.

Howarth, R. E. (1972). J. Nutr. 102, 37. 
James, W. P. T. \& Hay, A. M. (1968). F. clin. Invest. 47, 1958.

Jefferson, L. A., Li, J. B. \& Rannels, S. R. (1977). J. biol. Chem. $252,1476$.

Kirsch, R., Frith, L., Black, E. \& Hoffenberg, R. (1968). Nature, Lond. $217,578$.

Krebs, H. A. (1972). Adr. Enzyme Reg. 10, 399.

Laurent, G. J., Sparrow, M. P. \& Millward, D. J. (1978). Biochem. f. 176. (In the Press).

Lo, C. C. \& Millward, D. J. (1977). Proc. Nutr. Soc. 36, 137 A.

Luft, R. \& Hall, K. (1975). Advances in Metabolic Disorders. vol. 8. London, New York: Academic Press.

Millward, D. J. (1978). Biochem. Soc. Trans. 6, 494.

Millward, D. J., Bates, P. C., Laurent, G. J. \& Lo, C. C. (1978). In Protein Turnover and Lysosomal Function [H. L. Segal and D. Doyle, editors]. New Yort and London: Academic Press.

Millward, D. J., Garlick, P. J., James, W. P. T., Nnanyelugo, D. O. \& Ryatt, J. S. (1973). Nature, Lond. 24x, 204.

Millward, D. J., Garlick, P. J., James, W. P. T., Sender, P. \& Waterlow, J. C. (1976). In Protein Metabolism and Nutrition (E.A.A.P. publication 16 ), p. 49. London and Boston: Butterworths.

Millward, D. J., Garlick, P. J. \& Nnanyelugo, D. O. (1975). Proc. Nutr. Soc. 34. 33A.

Millward, D. J., Garlick, P. J., Nnanyelugo, D. O. \& Waterlow, J. C. (I976). Biochem. f. 156, 185.

Millward, D. J., Garlick, P. J., Stewart, R. J. C., Nnanyelugo, D. O. \& Waterlow, J. C. (1975). Biochem. f. 150, 235 .

Millward, D. J., Nnanyelugo, D. O., James, W. P. T. \& Garlick, P. J. (1974). Br. f. Nutr. 33, 127.

Millward, D. J. \& Waterlow, J. C. (1978). Fedn Proc. Fedn Am. Socs exp. biol. 37, 2283.

Mortimore, G. E. \& Ward, W. F. (1976). In Lysosomes in Biology and Pathology [J. T. Dingle and R. T. Dean, editors], vol 5, p. I 57. North Holland, Amsterdam: Elsevier.

Moss, F. P. \& Leblond, C. P. (1970). F. biophys. biochem. Cytol. 44, 459.

Pain, V. M., Clemens, M. J. \& Garlick, P. J. (1978a). Biochem, 手. 172, 129.

Pain, V. M., Garlick, P. J. \& McNurlan, M. A. (1978b). Proc. Nutr. Soc. 37, 29 A.

Peters, T. \& Peters, J. C. (1972). F. hiol. Chem. 247, $3^{85^{8}}$.

Picou, D. \& Taylor-Roberts, T. (1969). Clin. Sci. 36, 283.

Pimstone, B. L., Becker, D. J. \& Hansen, J. D. L. (1973). In Endocrine Aspects of Malnutrition, [L. I. Gardner and P. Amacher, editors]. Kroc Foundation Symposia, No. I, p. 73. Santa Ynez, California: Kroc Foundation.

Portnay, G. I., O'Brian, J. T., Bush, J., Vagenakis, A. G., Azizi, F., Arky, R. A., Ingbar, S. H., Brauerman, L. E. (1974). Y. clin. Endocr. Metab. 39, 191.

Pozefsky, T., Tancredi, R. G., Moxley, R. T., Dupre, J. \& Tobin, J. D. (1976). F. clin. Invest. 57, 444.

Rannels, D. E., Pegg, A. E., Rannels, S. R. \& Jefferson, L. S. (1977). Fedn Proc. Fedn Am. Socs exp. biol. 36, 1647 .

Ruderman, N. B. (1975). A. Rev. Physiol. 44, 245.

Shoji, S. \& Pennington, R. J. (1977). Mol. Cell endocr. 6, 159.

Spady, D. W., Payne, P. R., Picou, D. \& Waterlow, J. C. (1976). Am. f. clin. Nutr. 29, 1073.

Standard, K. L., Wills, V. G. \& Waterlow, J. C. (1959). Am. F. clin. Nutr. 7, 27 I.

Stewart, D. M. (1972). In Regulation of Organ and Tissue Grocoth, p. 77 [R. J. Goss, editor]. New York and London: Academic Press.

Waterlow, J. C., Cravioto, J. \& Stephen, J. M. L. (1960). Adv. Protein Chem. 15, 131.

Waterlow, J. C., Garlick, P. J. \& Millward, D. J. (1978). Protein Tumover in Mammalian Tissues and in the Whole Body. North-Holland, Amsterdam, New York: Elsevier.

Waterlow, J. C. \& Stephen, J. M. L. (1967). Clin. Sci. 33, 489.

Whitehead, R. G. \& Lunn, P. G. (1979). Proc. Nutr. Soc. 38, 69.

Whitehead, R. G. \& Alleyne, G. A. O. (1972). Br. med. Bull. $28,72$.

Woodside, K. H. \& Mortimore, G. E. (1972). \%. biol. Chem. 247, 6474.

Woodside, K. H., Ward, W. F. \& Mortimore, G. E. (1974). F. biol. Chem. 249, 5458.

Young, V. R., Haverberg, L. N., Bilmazes, C. \& Munro, H. N. (1973). Metabolism 22, 1429.

Young, V. R. \& Munro, H. N. (1978). Fedn Proc. Fedn Am. Socs exp. biol. 37, 2291. 